\title{
When the smoke cleared: Tobacco supply and consumption by the British Expeditionary Force, \\ 1914-1918
}

\section{Henry Daniels}

\section{(2) OpenEdition \\ Journals}

Electronic version

URL: http://journals.openedition.org/rfcb/218

DOI: $10.4000 / \mathrm{rfcb} .218$

ISSN: 2429-4373

Publisher

CRECIB - Centre de recherche et d'études en civilisation britannique

\section{Printed version}

Date of publication: 15 January 2015

ISSN: 0248-9015

Electronic reference

Henry Daniels, « When the smoke cleared: Tobacco supply and consumption by the British

Expeditionary Force, 1914-1918 », Revue Française de Civilisation Britannique [Online], XX-1 | 2015,

Online since 01 May 2015, connection on 19 April 2019. URL : http://journals.openedition.org/rfcb/218 ; DOI : 10.4000/rfcb.218

This text was automatically generated on 19 April 2019.

\section{(i) $\odot$

Revue française de civilisation britannique est mis à disposition selon les termes de la licence Creative Commons Attribution - Pas d'Utilisation Commerciale - Pas de Modification 4.0 International. 


\title{
When the smoke cleared: Tobacco supply and consumption by the British Expeditionary Force, 1914-1918
}

\author{
Henry Daniels
}

\section{Introduction}

1 This paper traces the rise of the cigarette from its timid mid-nineteenth century beginnings to its triumph not only as the preferred mode of tobacco consumption in the twentieth century and as an essential component in the British war effort 1914-1918, but also its symbolic role in the emancipation of women and its undoubted contribution, through branding, packaging and advertising, to what might be termed the design (in the cinematographic sense) of life at the time of the Great War. Strangely, apart from Princess Mary's Christmas 1914 gift box, ${ }^{1}$ the question of smoking in the armed forces does not appear to have attracted much academic attention. This omission is in all probability due to the sparsity of military archival material relating specifically to tobacco supply, to the ephemeral nature of most packaging and advertising material, to the disappearance of thousands of small tobacco manufacturers and retailers and to the relative absence of anything but passing allusions to tobacco from official histories and personal accounts. This study is an attempt to bring together a quantity of information drawn from many disparate and unconnected sources.

We shall see how, despite the awareness and serious warnings of the health risk involved in smoking, first technology then the reaction to American competition led to the development of a huge industry, dominated by the Imperial Tobacco Company of Great Britain and Ireland Ltd., whose rapid growth was closely bound up with the enormous upheaval and permanent sociological consequences of the Great War. 


\section{The social and psychological context}

3 In the introduction to the section entitled "Endurance for Scouts, or How to be Strong" of his 1908 bestseller Scouting for Boys: A Handbook for Instruction in Good Citizenship, the controversial hero of the siege of Mafeking, Lieutenant-General Robert Baden-Powell, commenting on what he calls "the deterioration of our race", points out:

Our standard of height in the army was $5 \mathrm{ft}$. $6 \mathrm{in}$. in 1845; it was FOUR INCHES less in 1895. In 1900 forty-four men in every thousand recruits weighed under 7st. $12 \mathrm{lbs}{ }^{2}$ in 1905 this deficiency has increased to seventy-six per thousand. (p.184)

Concluding:

For these reasons, the following chapter suggests the instruction of boys in being PERSONALLY RESPONSIBLE for their own Strength, Health and Sanitary Surroundings." (p.185).

B-P has the following advice for would-be juvenile smokers:

A SCOUT does not smoke.[...] He knows that when a lad smokes before he is fully grown up it is almost sure to make his heart feeble. [...] Any scout knows that smoking spoils his eyesight, and also his sense of smell, which is of greatest importance to him for scouting on active service. (p.198)

4 He goes on to list the names of public figures, soldiers, sailors and sportsmen as examples of non-smokers. On a more psychological level, he states:

No boy ever began smoking because he liked it, but generally because either he feared being chaffed by the other boys as afraid to smoke, or because he thought that by smoking he would look like a great man-when all the time he only looks like a little ass.

So don't funk, but just make up your own mind for yourself that you don't mean to smoke till you are grown up; and stick to it. That will show you to be a man much more than any slobbering about with a half-smoked cigarette between your lips.[...] (p. 198)

5 The reader is struck by something of an inconsistency in B-P's recommendations: great men, like scouts, do not smoke. Boys who smoke appear ridiculous and cause permanent damage to their health. However a grown up man can decide to smoke, apparently without risk to his health and without appearing to be "slobbering about", the unasked and unanswered question being: At what age does a boy become a man and a scout become a soldier ? Presumably the threshold is somewhere between the age of sixteen, at which tobacco could be legally bought, under the provision of the 1908 Children's Act, and the usual age of enlistment, viz.: eighteen to nineteen. Despite his noble intentions in appealing to all that is clean and wholesome in the male adolescent, B-P is perhaps underestimating the latter's growing wish to decide things for himself as well as his craving to attain manhood, or at least a semblance of it, by smoking successfully, i.e. without appearing ridiculous and without any signs of detriment to his health. It is also interesting to note that this tobacco warning, issued in 1908, is against cigarettes, with no mention of pipesmoking, chewing tobacco, cigars or snuff, though B-P points out later in the book that every family in the country would be $€ 7$ better off per year "[...] if the men gave up tobacco". (Baden-Powell, op. cit.: 199)

Why should cigarette smoking be associated in adolescents' minds with an image of manliness, despite the warnings of such influential and militarily-oriented people as Baden-Powell? The appeal of so-called "covert prestige", and peer-group identity and approval are obvious factors in any apparently devil-may-care posturing among male 
adolescents. However, in order to attempt to answer this question more precisely we need to look back to some of the events and attitudes of the nineteenth century.

Cigar-smoking was introduced into Britain by cavalry officers during and after the Peninsular War of 1804-1813. Prior to that, tobacco consumption had been a matter of chewing, snuff-taking and (usually clay-) pipe-smoking. This new fashion associated a patently phallic icon with the image of the glamorous rakishness of a militarised but idle elite (cf. Hilton, 2000: 42). The cigar also liberated the smoker of the paraphernalia that went with pipe-smoking and allowed him to discard the butt by tossing it into the fire or the gutter, which no doubt contributed to his nonchalant, libertine image. Meanwhile, such writers as J. M. Barrie in his famous My Lady Nicotine (1890) insisted on the feminine nature of tobacco as a concomitant of leisure and a source of satisfaction to be adored yet mastered. The cigar was almost exclusively a male attribute, associated with lightheartedness, after-dinner yarns and glasses of port, following the tactful withdrawal of the ladies, whose more delicate constitution might be affected by the smoke. Undoubtedly, then, by the middle of the century, the cigar was functioning as a symbol as well as an icon of powerful masculinity. ${ }^{3}$ What of the cigarette?

In his book Cigarette Pack Art (1979: 24), Mullen traces the appearance of cigarettes in Britain to the Great Exhibition of 1851, at which time two tobacconists, Bacon's (Cambridge) and Simmons (London), have records of selling cigarettes as opposed to cigars. Shortly afterwards, military men returning from the Crimean War popularised cigarette smoking, apparently a habit picked up from Turkish and Russian soldiers. As a result, the first cigarette manufactory in Britain was set up by Robert Gloag in London in 1856. For the next twenty-five years, cigarettes were hand-made, which kept them expensive and beyond the daily reach of working class smokers, who, let us remember, could obtain clay pipes free of charge in public houses. At that time cigarettes still had, despite their military associations, a connotation of effeminacy and foreignness (Hilton, op. cit.: 26-28). They were also reputedly insipid compared to the much stronger shags, rolls, plugs, twists, cakes, flakes and birdseyes ${ }^{4}$ favoured by working men. The picture changed dramatically when, in 1883, W. D. and H. O. Wills of Bristol purchased the exclusive rights to James T. Bonsack's cigarette making machine, capable of producing perfectly uniform cigarettes at the rate of 300 per minute. This enabled Wills to market, early in 1884, with the aid of a national advertising campaign, their first three brands aimed at a mass-market: Three Castles, ${ }^{5}$ Gold Flake and Louisville, followed four years later by Cinderella ${ }^{6}$ and the hugely successful Wild Woodbine ${ }^{7}$ all retailing at $1 \mathrm{~d}$ for a (paper) packet of five. Thus, the scene was set for a "Smoking Revolution" riding on the back of the 'Second Industrial Revolution'.

\section{"Tobacconomics": Creating the new consumer}

In order to maintain itself, the vast new market which was opening up had to be made to conform to the exigencies of the leading manufacturers, who had begun to use machines rivalling the Bonsack, thus, branding, packaging and advertising, the essential components in the fostering of a market capable of responding to and maintaining the new technology, was geared to what Hilton (op. cit: 5) describes as 'the lowest common denominators in society, appealing to the attractions of patriotism, the nation's past, the universal virtues of health and beauty and the optimism of the consumer-oriented future.' With the advent of the popular cheap-brand ${ }^{9}$ cigarette came the first elaborate, 
colourful packets pushing the virtues of their contents and featuring images with which any consumer would be glad to identify. From this period come brands such as Muratti's Tit-bits; Cope Bros.'s Peerless and Bouquet, Ogden's Guinea Gold; John Player's Weights and Navy Cut; Wills' Autumn Gold and Bristol (the latter had been launched in 1871). The flourish and exuberance of the packaging belied the standardisation of the market, a paradox which was to become the hall-mark of the twentieth century. Among the packets illustrated in the appendix are those in photo (2) Pirate: a celebration of Britain's glorious naval past linked, however, with the illicit adventures of piracy, thereby achieving a double appeal, and Passing Clouds: an anachronistic framed portrait of a $17^{\text {th }}$ century Cavalier smoking not a long-stemmed clay pipe as expected, but a cigarette. The use of ribbons and flowers and the pink background give an elegant, feminine, relaxed, dreamlike air. (6) Wild Woodbine, whose front is a typical fin de siècle precursor of Art nouveau in its use of harmonized colours, stylised plants and geometrical ornamentation gives an overall impression of late Victorian perfection with a touch of freshness.

10 The challenge facing manufacturers, in a context of traditional pipe- and cigar-smokers, who considered the inhalation of cigarette smoke as dirty and addictive, was that of how to convert the effete, tasteless and/or foreign connotation of the cigarette into something consumers could feel good about and even be proud of, hence the ever-increasing emphasis in packaging and advertising on notions of health, sport, military and naval glory and sexual attractiveness. Capital was also made of the relentless acceleration of the pace of life during the final years of the nineteenth century by way of the cigarette coming to represent an aid to dynamic living, rather than an idle pastime-an image long associated with pipe- and cigar-smoking. Meanwhile the briar we still know today was popularised during this period as a symbol of calm, manly dependability. ${ }^{10}$

11 As a result of James B. Duke of the American Tobacco Company's apparent attempt to take over the entire British tobacco industry in 1901, which was at that time in the hands of some 500 individual manufacturers, the thirteen biggest among them, led by W. D. \& H. O. Wills, 'closed ranks' and founded The Imperial Tobacco Company of Great Britain and Ireland, Ltd. There ensued the legendary 'Tobacco War' waged during 1901-1902 between the American Tobacco Company (hereafter ATC), represented in Britain essentially by Ogden \& Co. Ltd (Liverpool), which it had succeeded in acquiring, and the newly formed Imperial Tobacco Company (hereafter ITC). Undercutting of prices and the introduction of bonus systems, obliging retailers to stock only ITC or only ATC products, the inclusion of colourful and informative cigarette card stiffeners in paper packets and a huge increase in advertising expenditure were the main strategies employed during this fiercely competitive struggle. An agreement was signed on 27 September 1902, whereby the ailing Ogden's was sold to ITC for $£ 3$ million, while ATC withdrew from the UK, the terms being that neither the British nor the Americans would attempt to invade each other's market. Meanwhile, trade throughout the rest of the world would be the domain of the newly formed British American Tobacco (hereafter BAT), owned two thirds by ATC and one third by ITC. Duke's eager acceptance of this apportionment of the world market, proposed, it is thought, by Harry Wills, has led to speculation that such might have been his objective from the outset. Meanwhile, no doubt thanks partly to the renewed vigour of marketing brought about by the threatened American takeover, and the association of Empire and tobacco fostered by Victoria's diamond jubilee and the commercialised jingoism of the Boer War, British manufacturers had succeeded in creating the mass market for the cigarette. Baden-Powell had been bypassed, at least as far as smoking was 
concerned. The appendix contains (4) Diamond Queen: an example of good quality Empire kitsch, with its white embossed background, reminiscent of Victoria's lace cap. The use of gold and floral motif, surrounding a cameo of the Queen and her signature, gives the ensemble an air of stateliness and luxury.

\section{Tobacco and the Great War}

12 In this section we look firstly at the reaction of the public and the monarchy to the outbreak of war in as far as it articulated with the interests of the tobacco trade, secondly at the increasing prominence of ITC and in particular its dominant branch, W. D. \& H. O. Wills. Thirdly, we look briefly at the logistics of the supply of duty free cigarettes to troops at the front as evidenced by a glimpse of correspondence between Wills and the War Office in 1916.

\section{Tobacco supply}

13 An article dated $1^{\text {st }}$ September 1914 appearing in The Tobacco Trade Review ${ }^{11}$ (hereafter TTR), p. 352, reports what it calls "an entirely new departure on the part of the War Office", viz. "supplying free to each British soldier on the Continent $20 z$ a week of Wills's Capstan tobacco." This is in itself a scoop for Wills. The article also reports that the French national tobacco factories, are turning out, in addition to the c. fifty tons per day for the frontier regiments alone, unspecified quantities of especially sweet (Virginia) tobacco, which they call 'Tabac à la Confiture' destined for British troops. Meanwhile, a new brand of cigarettes La Cigarette Liégoise, done up in packets of twenty has been created in honour of the heroic resistance of the Belgians at Liège. The French market has seen the introduction of Vive la France brands of varying prices and qualities. It is reported also that the Germans realise the importance of the supply of tobacco to their troops, as they did in 1870, when "Millions of cigars followed them to the front [...]". Mention is also made of donations in the form of tobacco to the National Relief Fund, and of a new fund started under the patronage of Queen Alexandra to send tobacco to wounded soldiers and sailors in hospital. ${ }^{12}$ In the same article, certain retailers are reported as having offered special reductions of $20 \%$ off their prices "to all members of His Majesty's Forces. Orders received by post will be sent post free."

14 An announcement in the same edition states that "The Imperial Tobacco Company (of Great Britain and Ireland), Ltd., have donated $£ 25,000$ and the British American Tobacco Company, Ltd., $£ 15,000$ to the National Relief Fund of which H.R.H. the Prince of Wales is hon. Treasurer." ${ }^{13}$ That the potential of the mass market and the publicity and propaganda value of such patriotic gestures was clearly fully realised by the monarchy, by manufacturers and retailers in the first weeks of the war.

A short article in the October $1^{\text {st }}$ edition of the TTR (p. 379), entitled 'Tobacco for the Troops' mentions an unofficial scheme whereby "the purchaser of a packet of cigarettes is invited to add a similar packet to a collection set on one side for despatch to France and by this means some additional trade has been secured by some of the tobacconists who are suffering from the absence of customers with the forces." In short, those who have not answered their county's call are being offered the opportunity of supporting those who have, while maintaining the trade of "struggling tobacconists" whose regular customers are absent and are likely never to return: business as usual. 
The fact that the French and Belgian customs authorities had by this time agreed not to tax imported tobacco destined for British troops, coupled with the discount prices and various schemes and charitable organisations, meant that the men at the front were getting their supplies either free with their rations or reasonably cheaply.

1 But what did cheaply mean in real terms? Examples of minimum rates of pay as laid down by War Office Instruction $166(1914)^{14}$ add another perspective to the economics of smoking. Taking the ranks of private, sergeant and lieutenant as representative of Infantry troops serving at the front, we find that their minimum daily rates of pay ${ }^{15}$ were as follows. Private: $1 \mathrm{~s} 0 \mathrm{~d}$; sergeant: $2 \mathrm{~s} 4 \mathrm{~d}$; lieutenant: $8 \mathrm{~s} 6 \mathrm{~d}$. It emerges that, for the private soldier, a consumption of fifteen smokes a day (costing $3 \mathrm{~d}$ ) would probably be the maximum he could afford, unless regularly supplied from home. In contrast, a subaltern with the rank of lieutenant was in a position to consume more and better quality cigarettes.

By way of illustration, Wills' export summary for August $1915^{16}$ records a Cpt. M. Wilson, B.E.F. as having been sent 500 Gold Flake in tins of $100^{17}$ for the sum of $9 \mathrm{~s} 9 \mathrm{~d}$, plus postage 1s $9 \mathrm{~d}$ (cf. the June 1915 wholesale price of $£ 1$ s $6 \mathrm{~d}$ per $1,000^{18}$ ). A certain Spr A. Cameron, B.E.F. received 1,000 Three Castles in tins of 100 for the sum of $£ 1$ 1s, postage 1s $4 \mathrm{~d}$ (cf. June 1915 wholesale price of $£ 114 \mathrm{~s} 6 \mathrm{~d}$ per 1,000). These consignments appear to have been either handled or paid for by tobacconists. Spr Cameron, though benefiting from very favourable terms, is clearly spending well in excess of what his private soldier's minimal pay would allow, having just blued twenty days' pay on cigarettes. It must be remembered that the B.E.F. included in the ranks many middle class volunteers who would, fortunately, not be dependent on their pay to finance their pleasures.

The wholesale price of cigarettes, doubled over the period of the war. This $100 \%$ increase is, however, lower than that of most everyday foods and goods over the same period: C. S. Peel (op. cit.: 3) observes a 170\% increase in the retail cost of food between 1914 and 1918, while the average price of a bottle of whisky almost quadrupled, rising from $3 \mathrm{~s} 6 \mathrm{~d}$ to $12 \mathrm{~s}$ $6 \mathrm{~d}$. Relative to other everyday prices in 1914, cigarettes were easily affordable by most people in work, the most popular brands, such as Wills's Wild Woodbine, Cinderella, Ogden's Gold Flake, Player's Navy Cut "Medium" and Weights retailing at 1d for 5, allowing a man to smoke 10 cigarettes a day at a cost of $1 \mathrm{~s} 2 \mathrm{~d}$ a week. These few statistics serve to underline the relative cheapness, before and throughout the war, of smoking, which may well have acted as a substitute for drinking on many occasions, given the restricted licensing hours brought in during the autumn of 1917, the illegality of making a serviceman drunk even when off duty and the poor quality and high price of beer, which by 1917 had risen to $7 d$ (mild) and 10d (bitter) a pint. Regardless of such outdated recommendations as those of Baden-Powell, one of the side-effects of the war was to promote smoking-particularly cigarette smoking-as a cheap palliative to the suffering of an increasingly homogenised and undifferentiated mass: the prelude to the hugely profitable exploitation of mass markets that was to characterise the twentieth century. C. S. Peel (op. cit.: 106), speaking of the home front, says, "As time passed, chocolate became both scarce and nasty. Cigarettes, however, could be obtained without difficulty, and the nervous strain from which we suffered explained doubtless the increased consumption of them by men and women." The fact that she also mentions the case of "two land girls on leave, wearing their uniform [who were able] to enter a smart London restaurant, order as good a dinner as food scarcity permitted and sit unconcernedly smoking their cigarettes until it was served" (C. S. Peel op. cit.: 109) shows how novel such a spectacle still was. 
tobacco issued to the troops as part of their rations at the rate of $2 \mathrm{oz}$ per week (confirmed in the Field Service Pocket Book. 1914, Reprinted, with Amendments, 1916: 168), could be supplemented by duty free tobacco and cigarettes, essentially Red Hussar and Wild Woodbine, and, of course, by parcels sent from home, at reduced rates.

\section{W. D. \& H. O. Wills: the dominant branch of ITC}

In the years preceding the Great War, W. D. \& H. O. Wills, always the dominant branch of Imperial Tobacco, produced $45-50 \%$ of all cigarettes sold in the UK, while ITC as a whole accounted for over 70\% of total UK cigarette sales (Alford 1973: 315-316). As such, the activities of Wills deserve special attention here.

Its greatest commercial success, and the iconic brand which came to represent Wills and even the British troops, nicknamed "Woodbines" by the Australians (Brophy \& Partridge 1965: 206) was Wild Woodbine, launched in 1888. Six times more Woodbines, of which 8,000 million were sold in 1914, were being smoked than ITC's next largest selling brand, Player's Navy Cut "Medium".

23 The outbreak of war did not seriously affect the prosperity of Wills, who had made over £2m profits in 1911. Two minor details: out of courtesy to the French, the 'Waterloo' series of cigarette cards was discontinued, and, somewhat amusingly, eight German and Austrian personalities were removed from the series 'Musical Celebrities' in 1915 (Alford 1973: 320). Fortunately for Wills, their London sales, which had always lagged behind those of the provinces, were boosted, thanks to the very large numbers of soldiers stationed in and around the capital, while extensive files in the Wills archive bear witness to a regular trade in individual orders despatched to men serving in the armed forces.

It was not until 1916 that the War Office asked for tenders from manufacturers for the supply of tobacco and cigarettes to the troops. Wills, who were already in control of the $2 \mathrm{oz}$ (equivalent to around 40 cigarettes) weekly tobacco ration launched in September 1914, and whose cigarettes had been included in Princess Mary's well known Christmas 1914 gift box ${ }^{19}$ were now able to supply huge quantities of cigarettes and tobacco to the War Office in time for the battle of the Somme, as may be seen from the following table.

\begin{tabular}{|l|l|l|}
\hline & Share of Wills' total sales & Total weight supplied (lbs) \\
\hline 1916 (from May on) & Not available & 627,510 \\
\hline 1917 & $4.2 \%$ & $1,495,485$ \\
\hline 1918 & $6.7 \%$ & $2,480,839$ \\
\hline 1919 & $2.2 \%$ & 899,240 \\
\hline & & $5,503,074$ \\
\hline
\end{tabular}

Table 1. Tobacco and cigarettes supplied by Wills to the War Office 1916-1919 (adapted from Alford 1973: 321) 

tobacco and cigarette sales observed during the last two years of the war are, in the view of Alford (op. cit.: 323) due to an increase in smokers' rolling their own in response to the shortage of the finer tobacco required for cigarettes. To this one might add firstly the increase in women cigarette-smokers, many of whom had, for the first time in their lives, the pocket money to spend on smoking-an eloquent symbol of their emancipation, and secondly, the fact that conscription, introduced by stages throughout 1916, brought 
numbers of older men into the army, many of whom would have been pipe-smokers, at least at the time of their recruitment. The overall trend, however, was that of a decline in sales of smoking tobacco and a concomitant increase in the popularity of cigarettes.

Advertising, which had been stepped up as a result of the events of 1901, fell to an all time low during the war years. By 1918 advertising costs accounted for only $0.1 \mathrm{~d}$ for every pound weight of tobacco sold. Wisely, it was considered pointless to stimulate a need that manufacturers would have been unable to satisfy.

The main effect of the war on the UK tobacco industry was the arrival at a virtual monopoly for ITC (90\% of the market in 1920). Within the group, Player's Navy Cut "Medium" featuring the famous sailor's head enshrined in a lifebuoy, had become a serious rival to Woodbine, while in Scotland, Wills' Capstan ${ }^{22}$ continued to gain in popularity.

Whether things would have developed in the same way without the war is impossible to say. However, it does seem likely that factors such as the constant fear of the death of oneself and of loved ones, the food and coal shortages, the drab uniformity of life and the harsh working conditions at home, along with the unprecedented suffering of those involved in the fighting, all contributed to the seeking of the immediate and comfort afforded by that simplest of pleasures: the endlessly renewable cheap cigarette ${ }^{23}$.

\section{The Line of Communication}

41 The Wills collection file box 169 contains a small number of documents relating to the supply of cigarettes to the B.E.F. Among these is an unsigned, typed letter addressed to Mr Parks, dated 11 August 1916, concerning the tender for the supply of 108 million (270,000 lbs) Red Hussar cigarettes to be delivered at the rate of 9 million per week, commencing during the week ending 9 September 1916. The cigarettes are to be in packets of 10s, these packed in tins of $15 \mathrm{lbs}$, two to a case " [...] tins and cases to be marked with month and year of delivery. Cases also to be marked with the description and quantity of contents, name of contractors and with a distinctive number or mark (which is to be shown on invoice.)". The letter closes with the request, presumably in view of quality control: "Kindly send a sample 500 box of "Red Hussar" cigarettes to Officer Commanding, Supply Reserve Depot, Deptford Cattle Market, London, S.E. to reach him on Monday morning next." Wills' tender is accompanied by a letter dated 11 August 1916, in which apology is made for the company's inability to meet the deadline of 9 September, owing to two other tenders amounting to a total of $65,000 \mathrm{lbs}$ of cigarettes currently being dealt with: a clear indication that Wills were in a financially strong enough position to dictate terms to some extent. Another, undated, unsigned, handwritten W.O. document in the same file stipulates that "The cigarettes must be manufactured from a blend of tobacco of sound American growth or grown in British Colonies or Protectorates from American seed." It states also that deliveries can alternatively be made to "Willow Walk Goods Station in transit for Newhaven ${ }^{24}$ where final inspection will be made in accordance with clause 2 of contract. [...] Deliveries will be taken at all hours, day or night, but notification should be made in the case of deliveries proposed between 12 (midnight) and 5 a. m." There is no doubt that tobacco shipment was treated as a priority.

Once received at a French channel port, usually Dieppe, the "strong trade cases, suitable for export, whose gross weight was not to exceed $80 \mathrm{lbs"} \mathrm{(36} \mathrm{kg),} \mathrm{were} \mathrm{loaded} \mathrm{into} \mathrm{goods}$ 
wagons and found their way, via a regulating station, to the designated railhead, whence they were forwarded by horse-drawn or motorised supply columns either to YMCA stores or to their respective brigade depots, ${ }^{25}$ and finally brought up as needed by carrying parties moving under cover of darkness, under constant threat of shelling and machine gun fire, via a maze of tracks and zigzag communication trenches.

\section{Brands 1917}

In this section, we look at some 300 brands as indicators of the kind of images manufacturers were seeking to associate with tobacco in the minds of consumers prior to and during the Great War. The brand-names, most of which disappeared during the postwar years, constitute a part of the soldier's lexicon, as do trench slang, jargon and technical terms for weapons and munitions.

The Tobacco Year Book of 1918 includes an "Index of Brands of Tobacco, Cigars, Cigarettes, Snuffs etc., Comprising Names Advertised in the 'Trade Marks Journal' from May 3, 1876 to the end of October 1917." Thus, the index, which contains around 11,400 entries, without any indication of sales figures, beyond the appearance in bold type of the principal brands owned by the respective manufacturers, provides a near-exhaustive panorama of what might be termed 'the semiotics of tobacco marketing' in Britain during the first three years of the Great War.

\section{Common themes}

A perusal of the index reveals a flourishing market with a vast and exuberant array of brands, some of which fall neatly into themes, while others defy categorisation. Most are transparent, though many have no obvious link with tobacco, e.g. Barman; Barn Dance; Flower Queen; Fun; My Pet; Pink Book; Sunshine \& Shower; Upper Crust; Water Lily; White Cockade; Wit \& Wisdom. A minority are obscure, if not to say opaque, to the average customer, though may have had some local significance, e.g. Carbic (a kind of acid); Cardwag (obscure); Fylfot (a synonym of swastika); I. O. M. (presumably 'Isle of Man'); Ixion (a character of Greek Mythology); Moringa (a species of African tree); Nafas (Arabic for 'breath'); Nargrom (obscure); Potard (French slang for 'pharmacy student'); Uarda (an Arabic girl's name, meaning 'flower'); U. I. B. L. C. Corks (obscure); Vansum (obscure).

Among the best represented themes, are the following (five examples of each theme are given):

\section{Quiet relaxation and pleasure}

e.g. A Cool Smoke; A Quiet Pull; The Brain Lull; Dreamland; Evening Snooze.

\section{Carefree rakishness}

e.g. Cowboys; First Offence; Happy Dick; Woman's Rival; You Dirty Boy.

\section{Literary references}

e.g. As You Like It; Bloomsbury Shag; Tabard; Three Witches; Waverley. 
Humour (incl. reduplicatives and nonsense)

e.g. Kennel Club; ${ }^{26} \mathrm{Ki}-\mathrm{Ki}$; Nosewarmer; ${ }^{27}$ Scratchy Bits; Wild Oates [sic].

\section{Unfortunate and/or ageing bachelor}

e.g. Artful Codger; Old Bottle Neck; Old Soldier; Poor Old Ned; Same Dawg and the Same Piece of String.

Sport

e.g. Corner Kick; Cup Tie; Runners; Sporting Beauty; The Winner Shag.

\section{Nature/Pastoral}

e.g. Daybreak; Fresh Air; Meadowland; Summer Garden; Wild Woodbine.

\section{Local appeal}

e.g. Leeds Town Hall; London Docks; Manchester Ship Canal; Manchester Town Hall; Pride of Wharfedale.

The underlying appeal of these major themes is clearly of an emotional kind. The attempt on the part of the manufacturers to associate their products with feelings of fun, pride, leisure and relaxation rather than stressing the quality of the tobacco masks the increasing standardisation of consumer goods and the concomitant need to stimulate the customer's feelings of identification and loyalty.

We shall now look at two major themes, both relevant to the Great War. The first is that of brands evoking military and naval matters, the second, that of women, love and seduction-undoubtedly the central theme exploited in tobacco marketing in all countries at all times.

\section{Military and naval themes}

The Tobacco Year Book Index contains a total of 659 brands which are unmistakeably evocative of military and/or naval matters. Together, these amount to around $6 \%$ of the index: not a large percentage. It should be borne in mind, however, that among the military/naval brands were some of the best selling cigarettes and tobacco mixtures (e.g. Player's Navy Cut/Navy Cut Gold Leaf/Mild/Medium; Wills' Capstan; Major Drapkin's The Greys ${ }^{28}$ Wills' Red Hussar; which meant that reminders of military and naval glory, prowess and everyday life had a disproportionately high market profile. In the following lists a representative selection of brands are given, many of which clearly reflect the conditions of the present conflict. Given Britain's traditional dependence on her navy, it is somewhat surprising to find that 326 (c. 50\%) of the military/naval brands concern the army, as opposed to only 204 (c. 31\%) concerning the navy. This is perhaps a reflection of the massive and unprecedented recruitment into the army necessitated by the war. The 20 (c. $3 \%$ ) brands directly relating to the RFC/RAF reflect the comparatively small numbers of men concerned with aviation. 


\section{Military brands (325)} on sale during the Great War massively exploited the appeal of (particularly feminine) attractiveness, be it local or exotic, be it aggressive or romantic, be it aristocratic or homely. In all, the Tobacco Year Book Index lists a total of 1,132 brands explicitly relating to women. This theme, which accounts for c. $10 \%$ of all brands and is thus by far the most heavily exploited, may be subdivided into thirteen sub-themes. A maximum of ten representative examples of each sub-theme, presented in descending order of importance, are given. The fact that the totals of the categories do not add up to 1,132 is 
due to the considerable number of names falling into several categories and thus striking a chord, rather than a single note, e.g. Dusky Beauties (beauty + aggressive femininity); Venus de Cuba (beauty + exoticism).

\section{Exotic personal names (383)}

Carmelita; Dolores; Donna Rosa; Electra; Gracciella; ${ }^{36}$ Lolita; Natasha; Rosamunda; Silvana; Zuleika.

\section{Royalty/aristocracy (176)}

La Belle Duchesse; Court Beauties; Fancie Queen; Lany Jane Grey; Marie-Antoinette; La Monarca; Princess Yum Yum; Queen Mab; Reina Regenta; Zatma Pricesses.

\section{English personal names (excluding hypocoristics) (140)}

Angela; Bernice; Copelia; Eileen; Gladys; Hilary; Lorraine; Priscilla; Rowena; Stella.

Beauty (133)

Beauty's Eye; Bonnie Belle; Dunkirk Beauties; English Beauty; Hermosa; May Belle; Nature Beauties; Sleeping Beauty; Warsow's Imperial Beauties; Woodland Belle.

Young girls as an anonymous objects (including hypocoristics) (89)

Bit o' Fluff; Bonnie Lassie; Cherry Girl; Effie; Fairy; Girtie; Gypsy; Kitty; Lili; Mons Meg; ${ }^{37}$ Our Girls.

\section{Love and Romance (70)}

Amorosa; Besito; Cupidon; Kissing Cup; First Kiss; Old Flame; Il Bacio; Kiss-me-Quick; The Love Letter; Love's Delight.

\section{Exotic place-names (alluded to ${ }^{38}$ )}

Espagnola; Indian Queens; Levant Beauties; La Cubana; La Macedoine; Moon Maidens; La Reine des Antilles; La Russe; Spanish Senora; Virginia Belle.

\section{Subdued or neutral femininity (52)}

71 La Modesta; Modest Kate; Mother Hubbard; Mums; Old Maids; La Patriarca; El Santa; Santa Rosa; ${ }^{39}$ So Shy!; Woman's Rival.

\section{Aggressive femininity/seduction (51)}

Ah, Naughty!; Complaciente; Czarewitch; Dusky Queens; Flirtella; Kiss Curl; Lady Slavey; La Libertadora; Little Witch; La Seductiva. 


\section{Regional appeal (13)} front, on leave and while recovering from wounds, advertising, packaging and branding all having contributed to the triumph of smoking over concern about degeneracy, health and welfare as voiced by Baden-Powell in 1908. It has also revealed the supremacy of the cheap cigarette as the preferred mode of tobacco consumption by the end of the Great War. The Imperial Tobacco Co., the American Tobacco Co. and the British American Tobacco Co. all benefitted from the unprecedented demand resulting from mobilisation, generalised hardship and the emancipation of women, itself furthered by the war. Apart from a look at some of their brands in section 4 above, there has not been space to examine the contribution of the host of smaller manufacturers outside ITC, which would require a separate study.

Today's anti-smoking movement perhaps leads us to deplore the tobacco-dependency which was certainly established among countless millions of young people worldwide during the conflict. Nonetheless, at a time when comforts were few and life expectancy very short for so many people, tobacco, like alcohol, undoubtedly played significant and beneficial role in the maintaining of morale. ${ }^{40} \mathrm{Sad}$, though it is, a hundred years on, to think that so many went to their deaths having tasted so few of the real pleasures of life, these were desperate times: just like dancing, gambling, drinking and hasty and often sordid romance, the cigarette, along with the complex of images of glory and adventure associated with it, provided a passing illusion of a better life. It was, nationally and personally, a case of carpe foliam et fuma diem..$^{41}$ 


\section{BIBLIOGRAPHY}

Alford, B.W.E., W.D. \& H.O. Wills and the Development of the UK Tobacco Industry, London: Methuen, 1973.

Baden-Powell, R., Scouting for Boys, London: Pearson, 1928 [1908].

Barraclough, G., An Introduction to Contemporary History, Harmondsworth: Penguin,1967.

Barrie, J. M., My Lady Nicotine, London: Hodder \& Stoughton, 1902 [1890].

Fuller, J.G., Troop Morale and Popular Culture in the British and Dominion Armies 1914-1918, Oxford: Clarendon Press, 1990.

Hilton, Matthew, Smoking in British Popular Culture 1800-2000, Manchester and New York:

Manchester University Press, 2000.

The Imperial Story 1901-2001: Celebrating One Hundred Years, Bristol: Imperial Tobacco. 2002.

Mullen, Chris, Cigarette Pack Art: A Unique Blend of Cigarette Pack Design, Oldcastle: Galley Press, 1984.

Peirce, C.S., Ecrits sur le signe, Paris : Editions du Seuil, 1978.

Peel, C.S., How We Lived Then, 1914-1918: A Sketch of Social and Domestic Life in England during the War, London: John Lane, 1929.

Richards, Thomas The Commodity Culture of Victorian England: Advertising and Spectacle 1851-1914, London: Verso, 1991.

Terraine, John (ed.), General Jack's Diary: War on the Western Front 1914-1918, London: Cassell, 1964.

\section{Primary Sources}

Field Service Pocket Book. 1914, Reprinted, with Amendments, 1916. General Staff, War Office, HMSO.

Tobacco Trade Review Bristol Record Office, BRO refno 38169/J/4/28.

Wills collection BRO refno 38169/Sa/26/1, correspondence between Mr C. E. Parks of Wills at Bedminster and W. Rennie Esq., February-October 1916.

\section{APPENDIXES}

A selection of contemporary (Great War) cigarette packets

The following photographs are reproduced here by courtesy of The Wills Collection of Tobacco Antiquities at Bristol Museums Galleries \& Archives.

NB Guard book copies are models approved and preserved to ensure the conformity the printing of subsequent packaging material.

Photo (1): Wills' Capstan 10s 


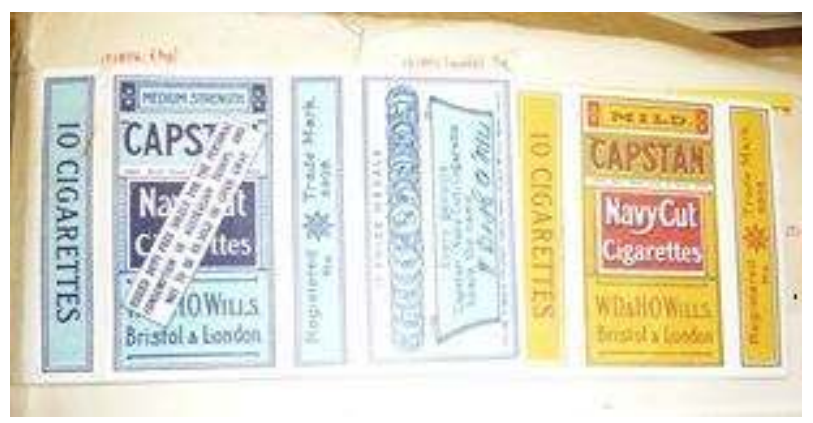

Guard book copies of two cardboard hull and slide packets featuring a clear naval theme: blue (medium strength, issued duty free solely for Australian troops) and yellow (mild). There is an overall impression of elegance and measured harmony of colours and forms. The rear of the packet shows prize medals awarded and signature. These, plus the use of gold lend an air of authenticity and a touch of restrained luxury. Capstan were particularly popular in Scotland.

Photo (2) Wills' Pirate and Passing Clouds

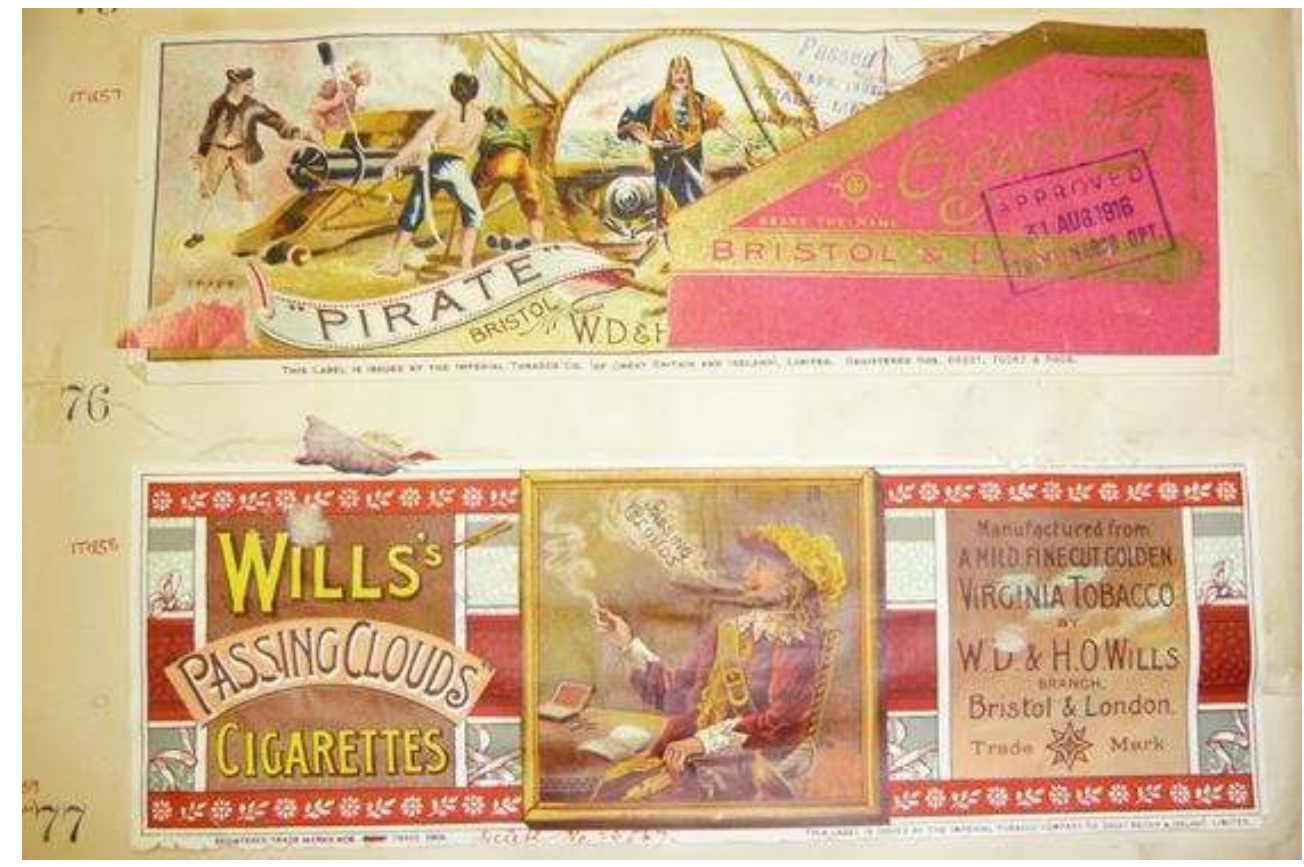

Guard book copies of two paper outer wrappers, date-stamped 28 April 1909. These are very ornate and attractive, with full colour printing.

Pirate: a celebration of Britain's glorious naval past linked, however, with the illicit adventures of piracy, thereby achieving a double appeal.

Passing Clouds: an anachronistic framed portrait of a $15^{\text {th }}$ century Cavalier smoking not a long-stemmed clay pipe as expected, but a cigarette. The use of ribbons and flowers and the pink background give an elegant, feminine, relaxed, dream-like air. These two wrappers of such a design could conceivably, with small modifications, be made suitable for confectionary or chocolates.

Photo (3) Wills' Capstan 20s 


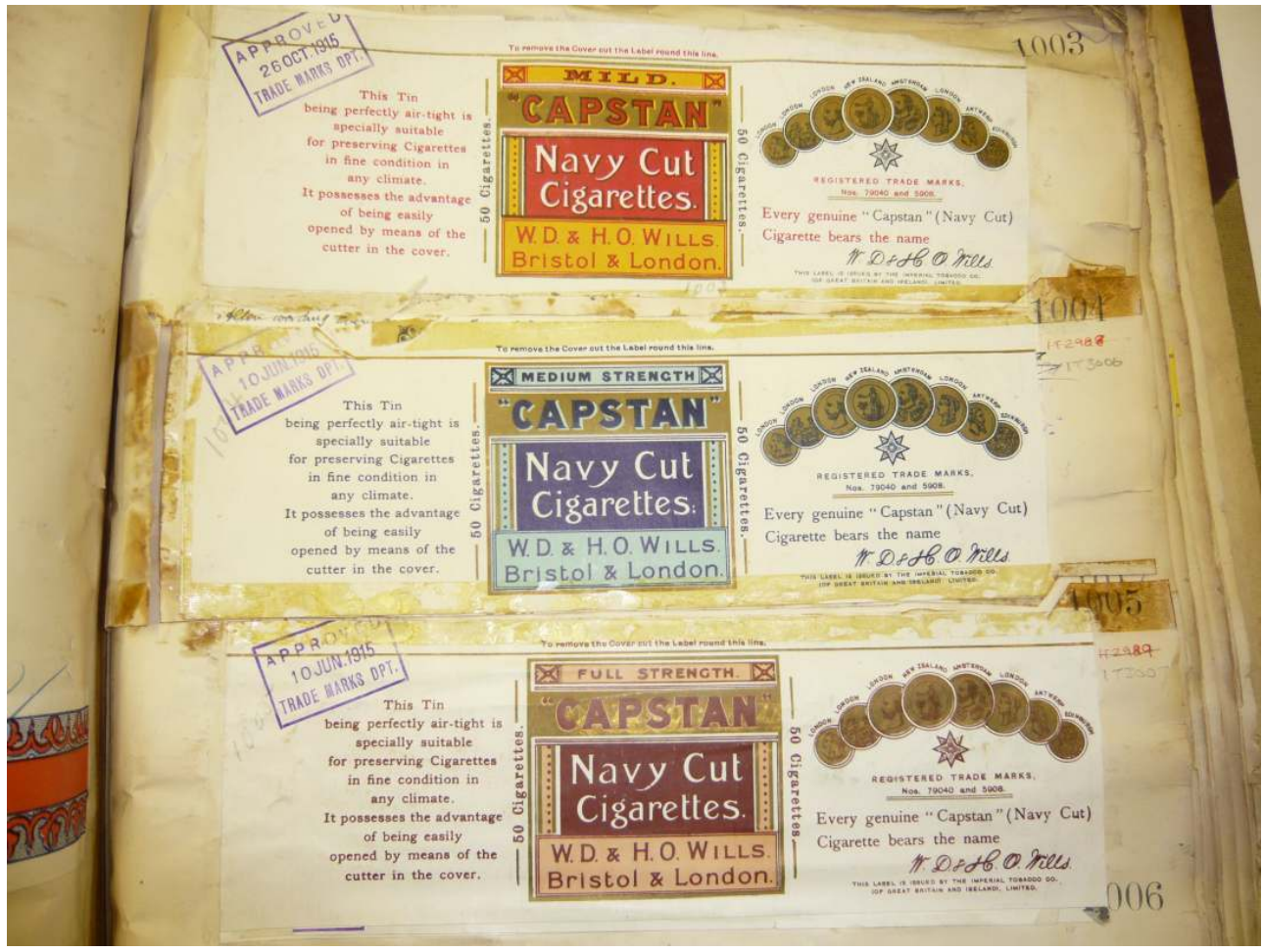

Guard book copies of three airtight drum wrappers, date-stamped 25 October and 10 June 1915. These are the three varieties of Capstan (mild, medium and full strength), cf. photo 627 above.

Photo (4) Cinderella 5s Diamond Queen 50s, Gold Flake 10s

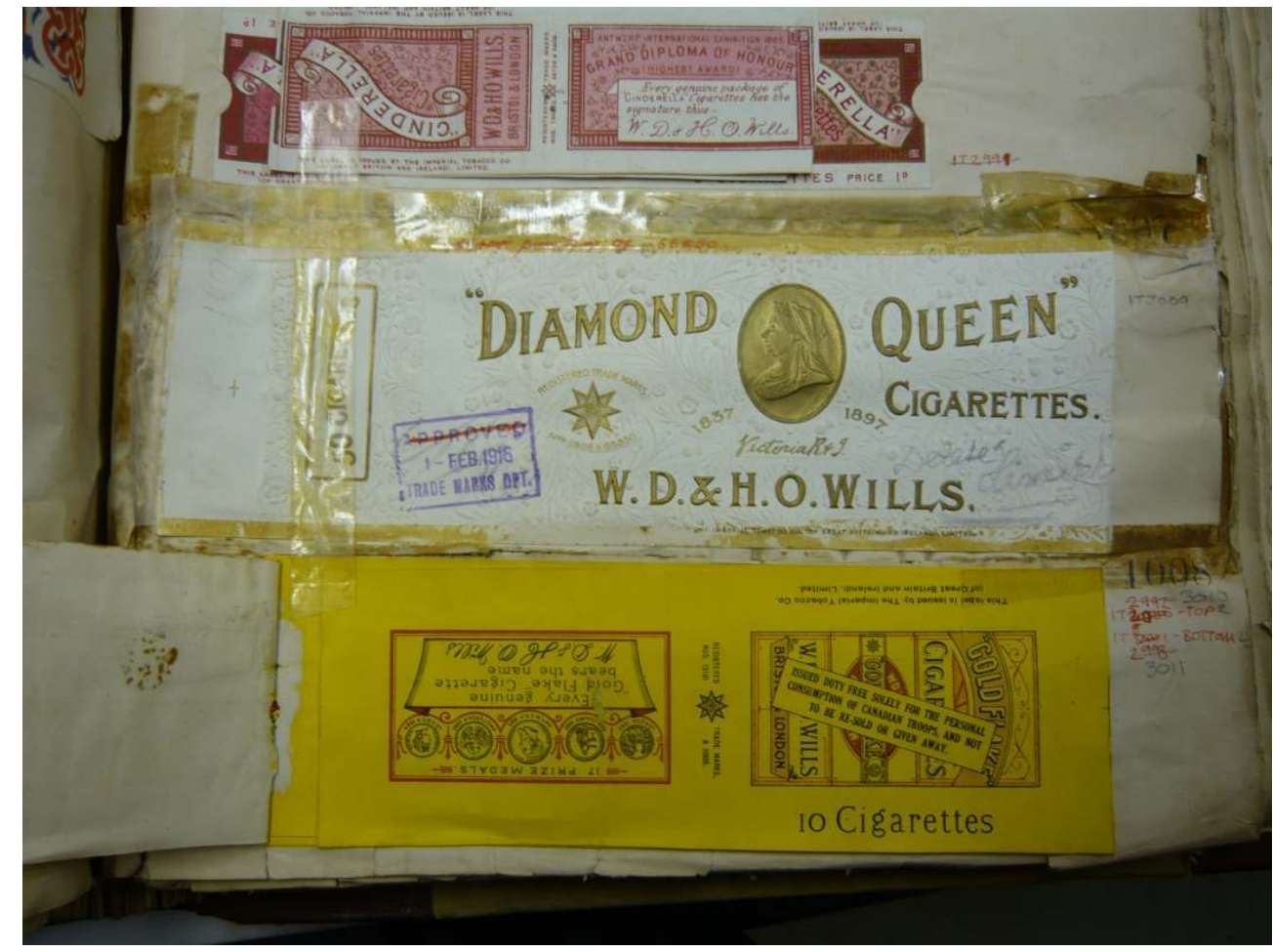

Guard book copies of two paper packets and one airtight drum wrapper. 
Cinderella: the sister brand to Wild Woodbine, this paper packet of 5's, with its intricate, harmonious and intimate pink and red design, exudes a dream-like, feminine appeal.

Diamond Queen 50s: an airtight drum wrapper in commemoration of Queen Victoria's Diamond jubilee (1897). Still on sale in February 1916 (date-stamped, though some amendment recommended: “delete L----- [illegible]"). This is an example of good quality Empire kitsch, with its white embossed background, reminiscent of Victoria's lace cap. The use of gold and floral motif, surrounding a cameo of the Queen and her signature gives the ensemble an air of stateliness and luxury.

Gold Flake 10s: issued duty free solely for Canadian troops. The design is bright, red and yellow, sophisticated and intricate. On the front and base of packet: Wills' compass rose. On the rear: five prize medals and the usual signature, giving an air of quality and authenticity.

Photo (5) 636 Red Hussar 10s and Heartsease 10s

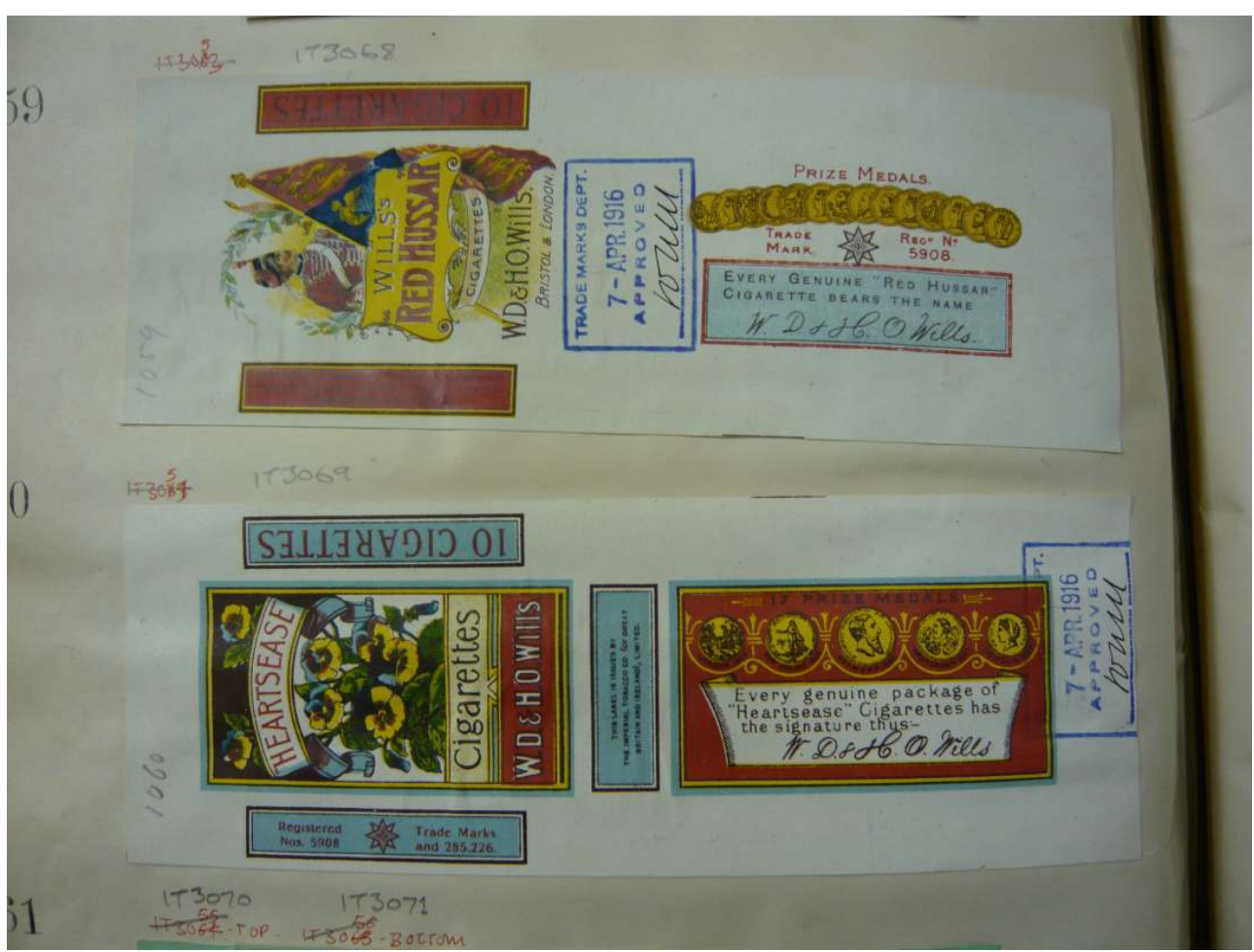

Guard book copies of two paper packets, date stamped 7 April 1917.

Red Hussar 10s: a bright and attractive allusion to military glory. The Hussar, the flag and the escutcheon bearing the brand name are set against a sunny, rustic background, decorated with branches and leaves. Bristol \& London printed in italics (unusual for Wills) On the rear: an impressive array of fourteen gold prize medals, overlapping, as worn on a military tunic.

Heartsease 10s: a paper packet, richly and symmetrically decorated with brightly coloured pansies (symbolising memory and nostalgia), and a scroll. Some small geometrical patterning. This very feminine packet could equally well be intended for sweets or perfume. Unusually, 'Bristol and London' is absent from the front. On the rear: the usual five gold prize medals. The name Heartsease is ambiguous, though reassuring and 
soothing, being a direct contradiction of, yet evoking, heart disease, which had already been identified as 'soldier's heart', one of the unfortunate consequences of smoking.

Photo (6) Wills' Wild Woodbine

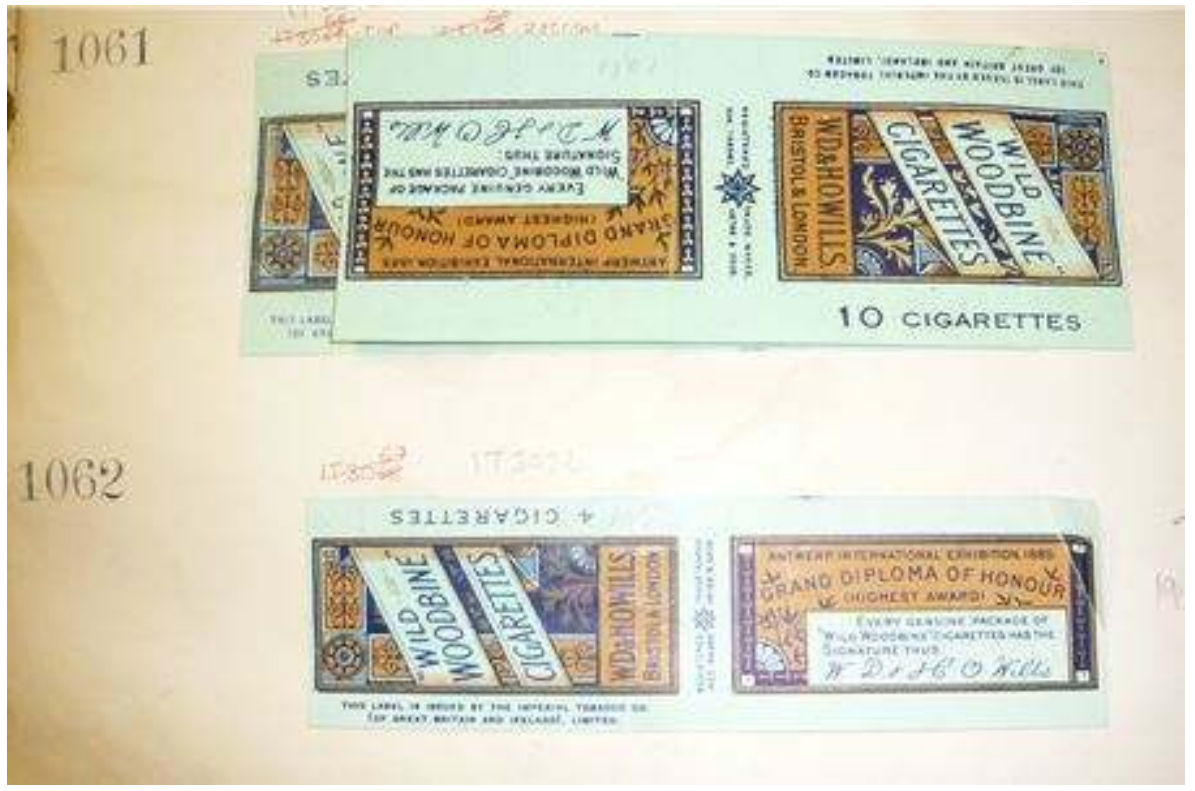

Two guard book paper packets, 10's and 4's of this most famous of all contemporary brands. The front is a typical fin de siècle precursor of Art nouveau in its use of harmonized colours, stylised plants and geometrical ornamentation. It gives an overall impression of late Victorian perfection with a touch of freshness. The 4's packet is possibly intended for use in a vending machine.

Photo (7) Wills' Gold Flake 50s airtight drum

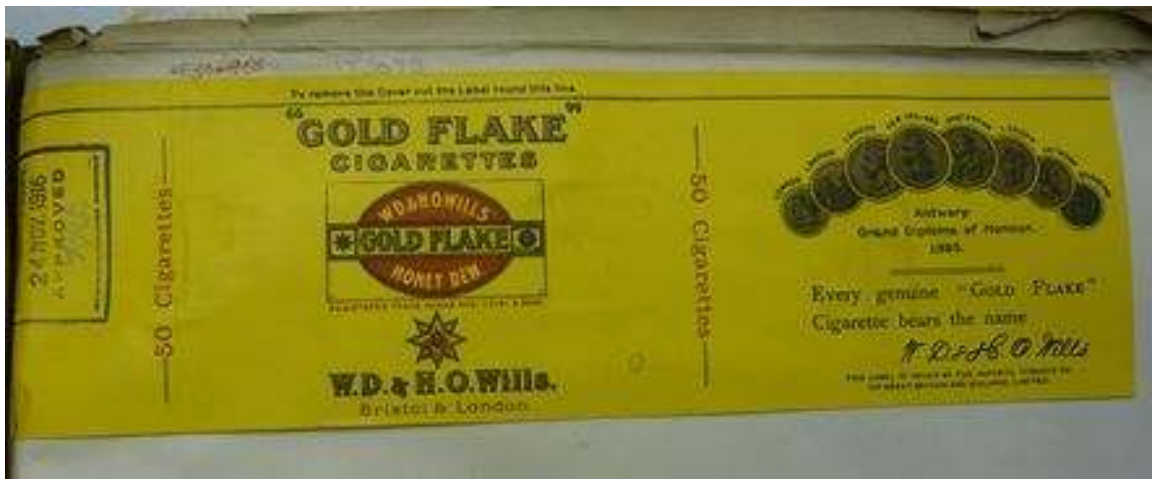

An attractive and brightly coloured yet sober airtight drum wrapper. The design is balanced and symmetrical. The red oval shape could conceivably be mistaken for a woman's cherry-red lips with the brand "Gold Flake" printed in gold between them. Recall that a drum is not intended for the pocket, but is to be placed prominently and enticingly on a shelf or on a piece of furniture.

Photo 8 Wills' Three Castles 10's 


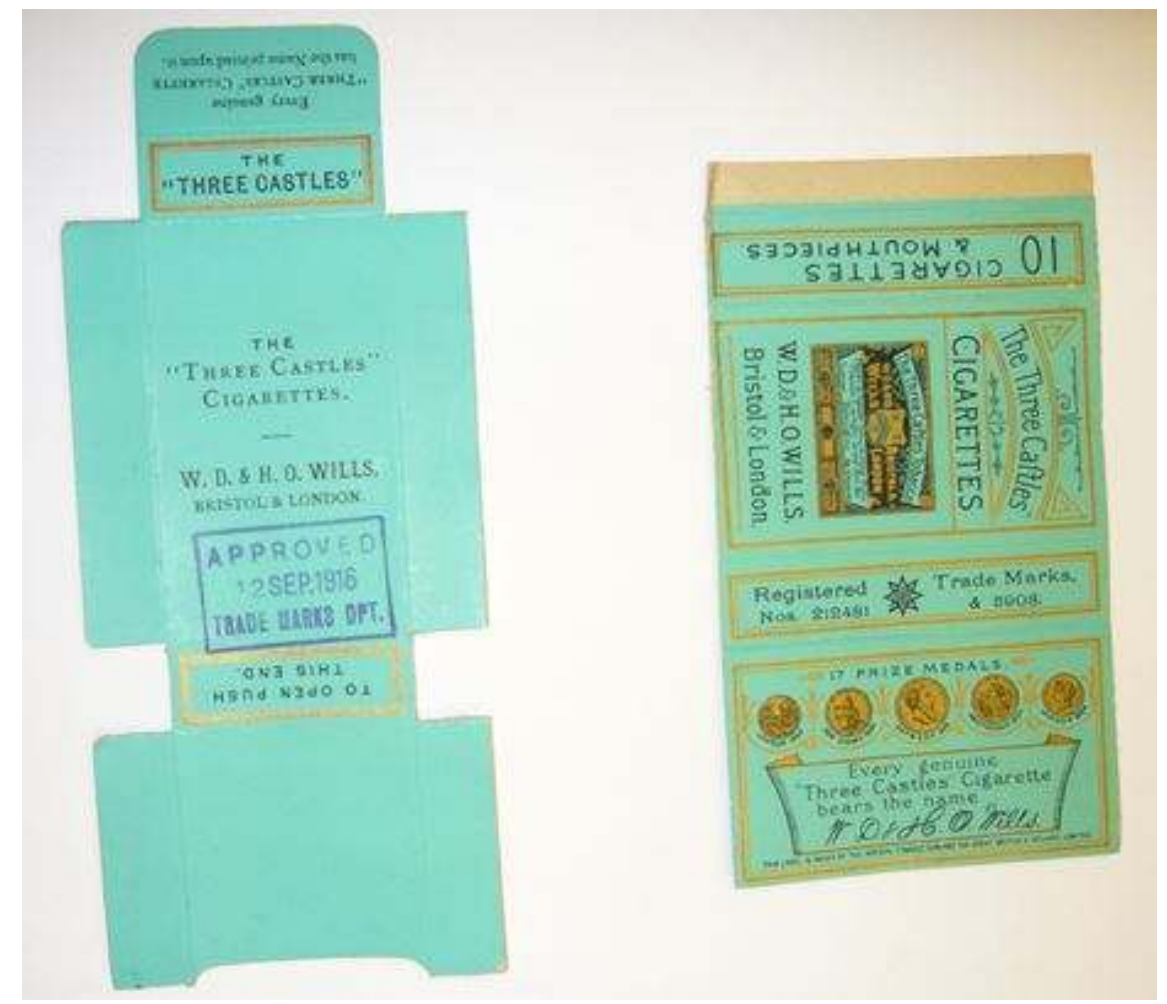

A cardboard hull and slide 10's packet, date-stamped 12 September 1916. The front is rich, yet restrained, the attractive contrasting colours giving an air of freshness. The escutcheon, reminiscent of that of The Salvation Army suggests an elite society, protection and solidity, as do the brand name, the chevron and the three turrets on the escutcheon. The mediaeval <s> also suggests long-standing tradition. Notice also the quotation from Thackeray's The Virginian: 'There's no sweeter tobacco comes from Virginia \& no better brand than the "Three Castles". The rear of the packet shows the usual five gold medals and the signature, while the slide resembles of the front cover of a book with the title and the name of the author underneath. The overall impression is one of quality, harmony and tradition.

Photo (9) Wills' Gold Flake Honeydew 100's hinged tin and a 10's hinged tin 


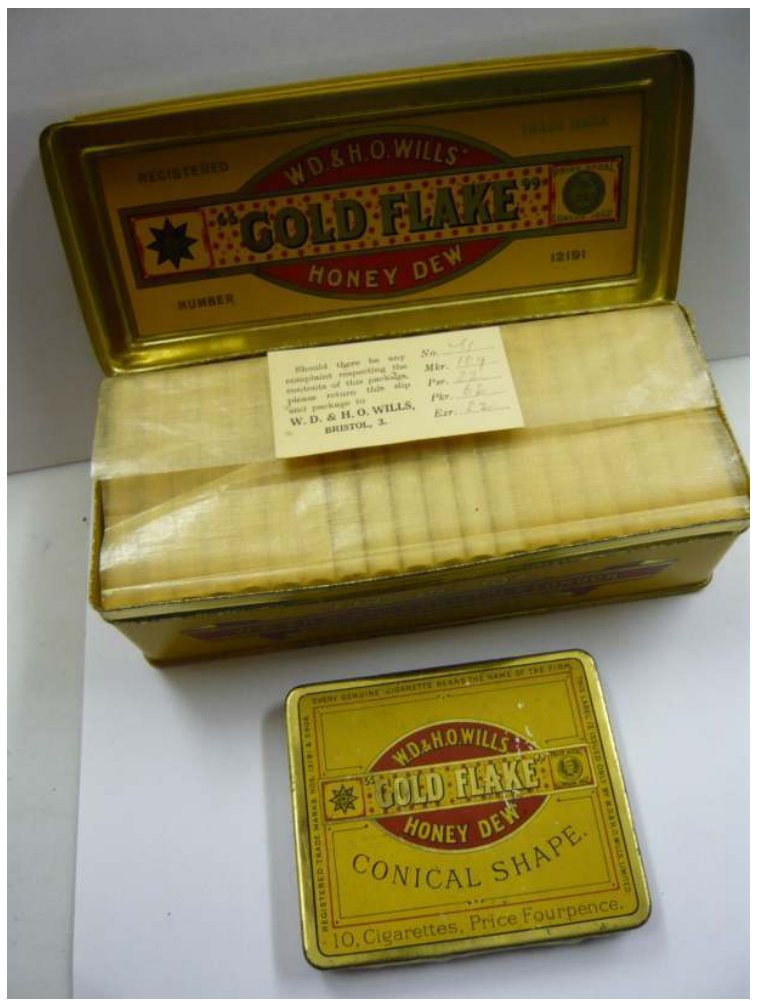

Two tins of conical shape Gold Flake cigarettes. The warm and contrasting colours are used to enhance the polka dot background to the brand name. These cigarettes were found to have preserved their delicate aroma almost 100 years after their manufacture.

Photo (10) 692 Wills' 50's airtight drum universal lid

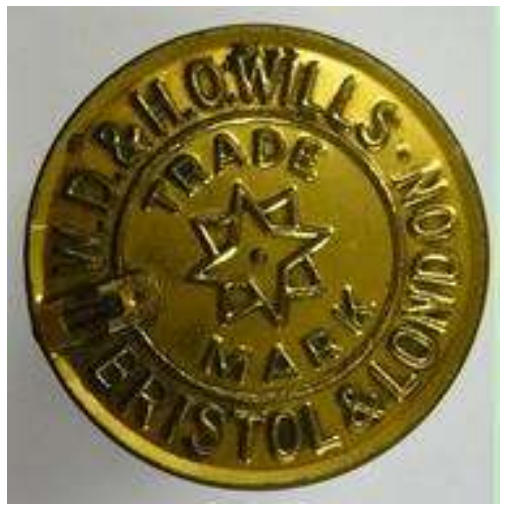

All Wills' airtight drums have this sealed lid, which bears the name W. D. \& H. O. Wills, Bristol \& London and the compass rose trademark.

Photo (11) Wills' Wild Woodbine 50's airtight drum 


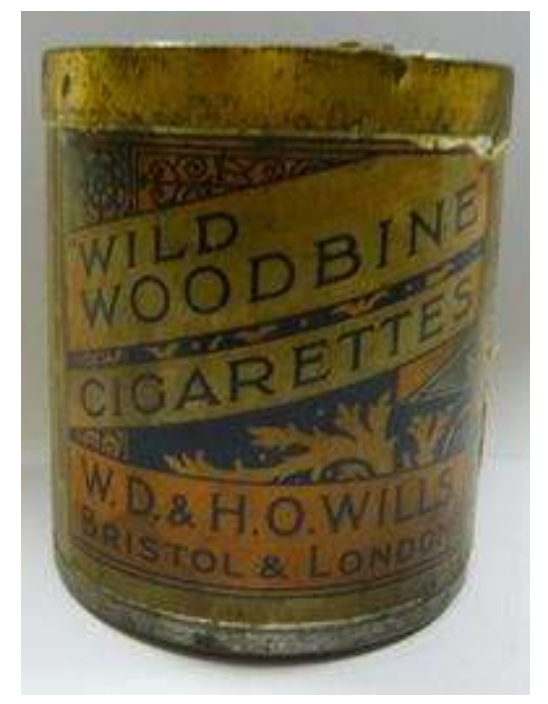

See photo (6) above. The lettering is bolder on the airtight drum than on the Wild Woodbine packets.

\section{NOTES}

1. See below: 3.2.

2. $110 \mathrm{lb}=$ c. $50 \mathrm{~kg}$

3. The terms icon and symbol are used in the technical sense given to them by C. S. Peirce (1978: 32).

4. For a definition of these terms, see Hilton (op. cit.: 49).

5. See appendix, photo (8).

6. See appendix, photo (4).

7. See appendix, photos (6) and (11).

8. G. Barraclough, 1967: 43-64.

9. W.D. \& H.O. Wills had introduced pre-packed tobacco branding in 1847 with Best Bird's Eye and Bishops Blaze [sic.].

10. The reassuring, dependable image of the pipe-smoker was to be exploited by Harold Wilson, who, in private smoked cigarettes.

11. Bristol Record Office (BRO refno 38169/J/4/28)

12. Among the many funds and organisations set up to provide for the needs of soldiers and sailors, including the supply of tobacco, were Soldiers' Comforts Fund; Sailors' Comforts Fund; the Blinded Soldiers and Sailors Care Committee; the King George and Queen Mary canteen; the Maple Leaf; the Y.M.C.A., the Y.W.C.A. (C. S. Peel, 1929: 30-31). Peel later compares the ubiquity of the figure of the VAD to that of "the wounded soldier in his blue suit and red tie and the cigarette without which he did not seem complete." (C. S. Peel, op. cit.: 127)

13. The Prince of Wales' appeal on behalf of the National Relief Fund produced the staggering sum of $£ 400,000$ in subscriptions during the following two days. (C. S. Peel, op. cit.: 28)

14. See the Long, Long Trail website http://www.1914-1918.net/

15. Regulations state that "additional proficiency pay is payable if the soldier fulfils certain conditions as to service and qualification: rates $3 \mathrm{~d}$ or $6 \mathrm{~d}$ per day, according to proficiency."

16. BRO refno $38169 / \mathrm{Sa} / 26 / 2$.

17. See appendix, photo (9). 
18. W. D. and H. O. Wills's Revised (wholesale) Price List of December 1914 advertises Capstan Navy Cut "Medium" cigarettes at 21s 6d per 1,000. Cheaper brands such as Red Hussar and Wild Woodbine sell for $14 \mathrm{~s} 8 \mathrm{~d}$. Three Castles cost $£ 114 \mathrm{~s} 6 \mathrm{~d}$ per thousand. These prices were still valid in June 1915. However, by July 1916, the price of Capstan Navy Cut "Medium" had risen to $£ 1$ 9s per thousand, Red Hussar and Wild Woodbine to $19 \mathrm{~s}$ and Three Castles to $£ 22 \mathrm{~s} 6 \mathrm{~d}$ per thousand. By August 1917 the corresponding rates were up to $£ 1$ 13s 6d, $£ 1$ 3s and $£ 2$ 3s. In April 1918, they stood at $£ 21 \mathrm{~s} 6 \mathrm{~d}, £ 11 \mathrm{~s} 3 \mathrm{~d}$ ( $£ 17 \mathrm{~s} 3 \mathrm{~d}$ for Wild Woodbine) and $£ 211 \mathrm{~s} 6 \mathrm{~d}$.

19. In the tradition established by Queen Victoria's 1887 and 1897 Jubilees, the dated, gilded embossed brass souvenir gift box was a perfect example of what Richards (1990: 90-95) defines as Jubilee Kitsch. The box serves to impress upon each serviceman the power of the all-providing monarchy and the combined strength of the Allies, while it confers upon him the status of maker of history and possessor and defender of its symbols. Cpt. J.L. Jack records in his diary entry for January $2^{\text {nd }} 1915$ '[...] Princess Mary has generously sent to each officer and man a pretty embossed brass box containing tobacco, and a pipe.'

20. See appendix, photo (5).

21. The problem was one of limited shipping space available on trans-Atlantic convoys, not one of loss of leaf through enemy action. Alford (op. cit.: 323) points out that only 1,326 casks, of a total of 295,594 casks shipped from the U.S. between 1914 and 1918, were lost at sea.

22. See appendix, photos (1) and (3).

23. There was, among men at the front a firm belief that the same match should not be used to light the cigarettes of more than two men. This apparent suspicion relates, so it is said, to the sniper's three operations: 1) spot the light; 2) take aim 3) fire.

24. Transport to Newhaven was handled by the London, Brighton and South Coast Railway (L.B.S.C.R.).

25. Canteens were not authorized until early 1915, as an unfortunate result of Lord Kitchener's proclamation of August 1914, 'This war is not going to be a picnic.' (Terraine, op. cit.: 83 FN)

26. Kennel Club: presumably an allusion to the smoker's being routinely 'in the dog house'.

27. Nosewarmer: compares favorably with the contemporary German Army slang term for a shortstemmed pipe: der Rotzkocher 'snot-cooker'.

28. The Greys: The Scots Greys Regiment.

29. Buffs: The East Kent Regiment.

30. Cordite: the smokeless propellant used in the manufacture of bullets and shells.

31. Glengarry: a traditional woollen Scots cap with a diced border, a large nickel regimental badge and ribbons hanging from the back.

32. Lyddite: A high explosive used for shells, named after the town in Kent where it was first developed.

33. We're Here: reminiscent of the marching song, sung to the tune of Auld Lang Syne, "We're here because we're here ...".

34. Drum Up: navy slang for 'make tea'. Drum is the navy equivalent of army mess-tin.

35. Taffrail: the rail around the stern of a ship (a corruption of Du. tafereel, "panel for painting or carving' < Lat. tabula 'board'.

36. Exotic names are occasionally misspelled or grammatically and lexically deviant, e.g. Empress de la India, or given a wrong gender, e. g. El Matrina; El Sabina.

37. This brand, which actually refers to the bombard presented to James II of Scotland by Plippe le bon, Duc de Bourgogne in 1454, and housed in Edinburgh castle in fact has a quadruple appeal, evoking simultaneously an earlier alliance, Edinburgh castle, the battle of Mons, and a homely girl.

38. This category consists essentially of the name of a feminine inhabitant of the place, e.g. La Doncella de Orleans; Levant Beauties.

39. The thirty saint's names are included in this category, by virtue of their vow of chastity. 
40. For a comprehensive account of morale and leisure on the Western Front, see Fuller (1990)

41. 'Pluck the leaf and smoke the day'.

\section{ABSTRACTS}

The changing image and eventual triumph of the cigarette over other forms of tobacco consumption during the fifty years prior to the Great War and its supply to British troops on the Western Front 1914-18 are examined here, along with with abundant examples of branding and packaging materials illustrative of the different types of appeal manufacturers sought to associate with cigarette smoking.

L'évolution de l'image et du triomphe définitif de la cigarette pendant la cinquantaine d'années qui a précédé la Grande Guerre et l'alimentation en tabac des troupes britanniques combattant au front ouest 1914-18 sont examinées ici. Figurent également de nombreux exemples de marques et d'emballages, illustrant les différentes formes d'attraction que les fabricants cherchaient à associer à la consommation de la cigarette.

\section{INDEX}

Mots-clés: Grande Guerre, histoire du Royaume-Uni, tabac, industrie

Keywords: Great war, British history, tobacco, industry

\section{AUTHOR}

\section{HENRY DANIELS}

Centre interlangues, Texte, image, langage, Université de Bourgogne 